\title{
Analysis Of The Causes Of JKN KIS Contribution Payment Arrears In The Working Area Of Kendari City "Study At The Abeli Public
}

\author{
Health” \\ Sartini Rizky ${ }^{1}$,Muhammad Ikhsan Akbar ${ }^{2}$ \\ ${ }^{1}$ Department of Magister Public Health Stikes Mandala Waluya Kendari, Indonesia \\ ${ }^{2}$ Department of Public Health Stikes Mandala Waluya Kendari, Indonesia \\ * Corresponding Author: Muhammad Ikhsan Akbar, Department of Public Health Stikes \\ Mandala Waluya Kendari, Indonesia, E-mail: muhikhsanakbar24@gmail.com, Phone: \\ $+6281354636426$
}

\begin{abstract}
Health Security Agency establishes the obligation to pay dues that must be followed in order to get health insurance society. But over time many participants BPJS is delinquent paying his dues BPJS. In June 2018 there were 711 souls who are still in arrears dues BPJS. This study aims to determine the factors associated with health BPJS arrears dues payments Independent in Puskesmas Abeli Kendari.

This research is an analytic study with cross sectional study. The population is all participants are in arrears in the health center BPJS Abeli Kendari as 711. Total sample of 88 respondents. This study using Chi-square test.
\end{abstract}


The results of statistical tests at the significance level $\alpha=0.05$, the result is no strong enough relationship between knowledge and dues payment arrears BPJS ( $\mathrm{p}$-value $=0.000$ ), there is a strong enough correlation between income with payment arrears dues BPJS ( $p$ Value- $=0.000$ ), there is a strong enough correlation between the perception of the arrears payment of dues BPJS $(\mathrm{p}$-value $=0.000)$.

The conclusion showed that the non-payment of dues BPJS in touch with all the variables. By him that suggested need for socialization of the BPJS that participants understand more about BPJS resulting in the payment of contributions of participants BPJS not delinquent.

\section{Keywords : Patient services BPJS satisfaction, Service speed, Service attitude, Drug availability}

\section{Introduction}

Health is a state of well-being of the body, soul and social that makes it possible for every individual to live productively in a social and economic way. In managing health problems, a special body responsible for organizing health insurance is needed, where the body must provide good quality of service in order to achieve health service satisfaction. In Indonesia a Health Social Security Organizing Agency has been established which is in line with the goals of the World Health Organization in developing health insurance for all residents. BPJS Kesehatan is a legal entity formed to organize health programs. ${ }^{1}$

Health is a human right and an element of well-being that must be realized in accordance with the ideals of the Indonesian people as referred to in the Pancasila and the Preamble of the 1945 Constitution. To realize the global commitment of each State to carry Universal Health Converage (UHC) for the entire population, the government is responsible for 
implementing National Health Insurance (JKN) program. The Social Security organizing body has been regulated by Law Number 24 of 2011 concerning the Social Security Organizing Agency (BPJS) . ${ }^{2}$

During the two years of the JKN program, not all Indonesians have been protected by JKN. This can be seen from the data on the number of health BPJS participants . Nationally, the number of BPJS Health participants in 2016 was 163 million out of 255 million people in Indonesia. BPJS Health must understand the needs of the public health services it serves in determining the most effective ways of providing quality health services. Health BPJS participants are divided into two laws, namely Participants Receiving Donation Assistance (PBI) and for the poor or disadvantaged families the government covers into the Regional Health Insurance program that has been integrated into the BPJS Recipient Assistance (PBI) recipient program. $^{3}$

In the BPJS program rules for premium payments are required no later than the 10th of every month. Arrears occur because there is no mutual cooperation mentality in terms of contributions. This is because most participants who register at BPJS Health are participants at risk of getting sick before their eyes. As participants who need immediate medical treatment (History of Disease) with expensive costs. Participants like this are enthusiastic in registering BPJS program membership, but after the medical treatment process is passed, participants are averse to the obligation to pay contributions. ${ }^{4}$

According to data from the Southeast Sulawesi Provincial Health Office in 2017 it is known that the number of independent BPJS users has only reached $65 \%$. And from the Southeast Sulawesi Provincial Health Office also showed that Kendari City achieved a new target of $68 \%$. According to the results of a report from the Health Office of Kendari City, one of 
the Subdistricts which is still low in the participants of the independent BPJS is Abeli Subdistrict, from the available quota when compared to Other Districts, such as the Kemaraya District and Nambo District. ${ }^{5}$

Based on the results of an initial survey in the work area of the Abeli Health Center that BPJS Mandiri membership is a membership that is dependent on their own willingness to pay contributions. In this case the social economy of the community influences the sense of want and willingness to pay participants to continue and obediently pay dues. The lower economic conditions of the community can lead to a sense of desire and ability of participants not to pay BPJS Mandiri contributions. On the other hand, based on the results of interviews with BPJS Mandiri participants, they said that they would pay contributions when they were already sick and they took care of and paid BPJS contributions, then the administration and payment process to the Bank which the participants felt was very complicated. dues felt by the participants were very burdensome for them.

Based on preliminary studies conducted by researchers, the data obtained that BPJS patient visits in the April 2018 period amounted to 376 patients, down from the February period the number of BPJS patients was 421 patients, and in January there were 477 BPJS patients. In addition, the coverage of independent BPJS in 2017 was $66.2 \%$, which still did not reach the 75\% target in 2017. The number of registered BPJS Mandiri members for the Abeli District Region for the 2017 period was 2,547 people. Data on BPJS contribution payment for the last 3 months is that in April 2018 there were 469 people (18.4\%) experiencing delays in payments, in May there were 342 people (13.4\%), and a drastic increase in June 2018 there were still 711 people ( $27.9 \%$ ) who are still in arrears on payments 'There are several factors that affect the regularity of paying health insurance contributions. Factors related to the willingness to pay 
BPJS contributions regularly can be influenced by several factors, namely Knowledge, income, average monthly expenses, ability to pay contributions, and willingness to pay contributions. In this study, the variable of willingness and ability to pay for JKN was not examined because when a JKN participant was present, someone was able and willing to pay contributions, the researcher added several variables in this study, namely knowledge, income and perception of arrears in payment of BPJS Mandiri contributions in the Abeli Community Health Center. ${ }^{6}$

\section{Methods}

This type of research is an analytic study with a cross sectional study design that is a study that wants to analyze the relationship between the dependent and independent variables, namely the relationship between the arrears in payment of contributions to the BPJS Mandiri with knowledge, income and perception and research conducted at the same time and place. This study was conducted in the month November 2018 was held at the Regional Public Health Center AbeliKendari. The population in this study were all BPJS participants who were delinquent in the working area of the Abeli City Health Center in Kendari City amounting to 711 people, and the sample in this study were 88 respondents with a simple random sampling method. Instrument or data collection tool in this study is a questionnaire. The statistical test of this study used the Chi squretest .

\section{Result}

The results of the study Table 1 shows that of 88 respondents largest age group is the age group most at the age group > 40 years as many as 39 respondents $(44,3 \%)$ and the smallest group aged 26-30 years of which three respondents (3.4\%). For education, 88 respondents showed that the highest education was 38 respondents (43.2\%) and the lowest was 2 
respondents $(2.3 \%)$. For the work of 88 respondents showed that the most work was selfemployed 47 respondents $(53.4 \%)$ and the smallest were entrepreneurs and housewives which were 8 respondents $(9,1 \%)$.

Table 1. Characteristics Respondents by Age, Education and Employment in Region Work Puskesmas Abeli Kendari

\begin{tabular}{lll}
\hline Characteristics & $\mathbf{n}(\mathbf{9 8})$ & $\mathbf{\%}$ \\
\hline Age & 3 & 3,4 \\
$26-30$ & 22 & 25 \\
$31-35$ & 24 & 27,3 \\
$36-40$ & 39 & 44,3 \\
$>40$ & $\mathbf{9 8}$ & $\mathbf{1 0 0}$ \\
Total & & \\
\hline Education & 2 & 2,3 \\
Elementry School & 12 & 13,6 \\
Junior High School & 38 & 43,3 \\
Senior High School & 17 & 19,3 \\
Diploma & 19 & 21,6 \\
College & $\mathbf{9 8}$ & $\mathbf{1 0 0}$ \\
Total & & \\
\hline Occupation & 47 & 53,4 \\
Entrepreneur & 12 & 13,6 \\
Trader & 21 & 28,9 \\
Fisherman / Seaman & 8 & 9,1 \\
Housewife & $\mathbf{9 8}$ & $\mathbf{1 0 0}$ \\
Total & & \\
\hline
\end{tabular}

Source: Primary data 2018

The results of Table 2 show that of 88 respondents (100\%), respondents with less knowledge were $48(54,5 \%)$ respondents, who were not delinquent as many as 8 (9.1\%) respondents and were delinquent as much as $40 \quad(45.5 \%)$. While respondents knowledge quite as many as $40(45,5 \%)$ of the respondents, who are not in arrears $26(29.6 \%)$ and in arrears by $14(15.9 \%)$ of respondents. Based on the ChiSquare statistical test results obtained $p$ value or significant value is 0,000 and $\alpha=0,05$. The 
value of $p$ is less than $\alpha(p<\alpha 0.05)$, the hypothesis means that $\mathrm{H}_{0}$ is rejected or $\mathrm{H}_{1}$ received, which means there is a relationship between non-payment of dues BPJS with respondents' knowledge at the health center Abeli Kendari City in 2018 .

The results of Table 2 show that of 88 respondents (100\%), respondents with less income were $58(65,9 \%)$ respondents, who were delinquent as many as $46(52.3 \%)$ respondents and were not delinquent as many as $12(13,6 \%)$. While respondents were income pretty much as $30(34,1 \%)$ of the respondents, which is overdue by $8(9.1 \%)$ and not in arrears by $22(25.0 \%)$ of respondents. Based on the Chi-Square statistical test results obtained $p$ value or significant value is 0,000 and $\alpha=0,05$. The value of $p$ is less than $\alpha(p<\alpha 0.05)$, the hypothesis means that $\mathrm{H}_{0}$ is rejected or $\mathrm{H}_{1}$ received, which means there is a relationship between non-payment of dues BPJS with income of respondents in Puskesmas Abeli Kendari City in 2018.

Table 2. Relationship of Arrears for BPJS fee payments with knowledge, income, perception at Abeli Health Center in 2018

\begin{tabular}{|c|c|c|c|c|c|c|c|}
\hline \multirow{3}{*}{ Variable } & \multicolumn{6}{|c|}{ Arrears in Payment of BPJS Contribution } & \multirow{3}{*}{ Statistic test } \\
\hline & \multicolumn{2}{|c|}{ In arrears } & \multicolumn{2}{|c|}{ No arrears } & \multicolumn{2}{|c|}{ Total } & \\
\hline & $\mathbf{n}$ & $(\%)$ & $\mathbf{n}$ & $(\%)$ & $\mathbf{n}$ & $(\%)$ & \\
\hline Knowledge & & & & & & & $\alpha=0.05$ \\
\hline Less & 40 & 45.5 & 8 & 9.1 & 48 & 54.5 & $p$-Value $=0,000$ \\
\hline Enough & 14 & 15.9 & 26 & 29.5 & 40 & 45.5 & \\
\hline \multicolumn{7}{|l|}{ Income } & \multirow{3}{*}{$\begin{array}{c}\alpha=0.05 \\
p \text {-Value }=0,000\end{array}$} \\
\hline Less & 46 & 52.3 & 12 & 13.6 & 58 & 65.9 & \\
\hline Enough & 8 & 9.1 & 22 & 25.0 & 30 & 34.1 & \\
\hline \multicolumn{7}{|l|}{ Perception } & \multirow{3}{*}{$\begin{array}{c}\alpha=0.05 \\
p \text {-Value }=0,000\end{array}$} \\
\hline Enough & 32 & 36.4 & 6 & 6.8 & 38 & 43.2 & \\
\hline Less & 22 & 25.0 & 28 & 31.8 & 50 & 56.8 & \\
\hline
\end{tabular}


The results of the study Table 2 shows that of the 88 respondents $(100 \%)$, respondents perception of both $50(56,8 \%)$ of the respondents, which is in arrears by $22(25.0 \%)$ of the respondents and do not overdue by 28 (31.8\%). While the perception of respondents who less were 38 ( 43 , $2 \%)$ of the respondents, which is in arrears by $32(36.4 \%)$ and not delinquent $6(6.8 \%)$ respondents. Based on the Chi-Square statistical test results obtained $p$ value or significant value is 0,000 and $\alpha=0,05$. The value of $p$ is less than $\alpha(p<\alpha 0.05)$, the hypothesis means that $\mathrm{H}_{0}$ is rejected or $\mathrm{H}_{1}$ received which means that there is a relationship between the non-payment of dues BPJS with the perception of respondents in Puskesmas Abeli Kendari City in 2018.

\section{Discussion}

Knowledge is a treasure of mental wealth directly or indirectly contributes to enrich our lives, therefore knowledge is a source of answers to various questions that arise in life. According to Notoatmodjo (2007), that sufficient knowledge about JKN affects the behavior of community participation in JKN. If the community lacks knowledge about JKN, it will have an impact on people's attitudes towards the program. ${ }^{7}$

The results of the study showed that of 88 respondents $(100 \%)$ the category of knowledge was less as many as 48 respondents ( $54,5 \%)$, who were in arrears in payment of as many as 40 respondents $(45.5 \%)$ this was due to the lack of respondents' income and there are respondents who say they often forget to pay dues, who are not in arrears as many as 8 respondents $(9.1 \%)$ this is because respondents are aware of the importance of paying dues to get proper health insurance. While respondents who have sufficient knowledge are 40 respondents $(45,5 \%)$, who are delinquent as many as 14 respondents $(15.9 \%)$ this is because respondents do not yet understand and know the importance of paying BPJS 
contributions, because routinely paying patients get proper health insurance, which is not overdue by 26 respondents $(29.5 \%)$. This is due to the fact that respondents get support and motivation from neighbors to routinely pay contributions on time as well as sufficient income .

Based on the statistical test result, $p(0.000)$ is smaller than $\alpha(p<\alpha 0.05)$, the hypothesis means that $\mathrm{H}_{0}$ is rejected or $\mathrm{H}_{1}$ received, which means there is a relationship between non-payment of dues BPJS with knowledge in the health center Abeli Kendari City in 2018.

This study is in line with research conducted by Nopiyani (2015) which says that there is a relationship between the level of knowledge about JKN and compliance with pay, the higher the JKN knowledge, the greater the compliance in paying fees. ${ }^{8}$ However, the results of this study are not in line with research conducted by Pratiwi (2015) which states that respondents have a sufficient level of knowledge but are not compliant to pay BPJS contributions independently due to factors such as many respondents who do not yet understand BPJS Health, lack of support from families, and in getting socialization about BPJS Health has not been effective. $^{9}$

Income is income arising from community activities each month according to the regional minimum per capita income wage standard. Theory by Kertayasa (2010) suggests that public income affects public awareness in insurance. The higher a person's income, the higher the people's awareness in insurance and paying contributions . ${ }^{10}$

The results of the study showed that out of 88 respondents $(100 \%)$ the income category was sufficient as many as 30 respondents (34.1\%), who were in arrears in payment of contributions of $8(9,1 \%)$ this was due to the knowledge of respondents who still did not understand the guarantee function health, and there are respondents who say they often forget to 
pay dues, which are not arrears as many as 22 respondents ( $25.0 \%)$ this is because respondents are aware of the importance of paying contributions to get adequate health insurance and sufficient income. While 58 respondents $(65,9 \%)$ earned less than 46 respondents ( $52.3 \%$ ) in arrears because respondents stated that mediocre income was the main factor in delay in paying BPJS contributions, which were not in arrears as much 12 respondents ( $13.6 \%)$ respondents. This is because respondents get support and motivation from family members who understand the rules of getting health insurance. Based on the statistical test result, $p(0.000)$ is smaller than $\alpha(p<\alpha 0.05)$, the hypothesis means that $\mathrm{H}_{0}$ is rejected or $\mathrm{H}_{1}$ received, which means there is a relationship between non-payment of dues BPJS with revenues in PHC Abeli of Kendari City in 2018.

Perception is part of an individual's assessment which is a characteristic of a need that makes it possible to seek treatment that can manifest in action if it is felt as a need. In other words, needs are the basis and direct stimulus for using health services. Perception is the act of compiling, recognizing, and interpreting sensory information to provide an overview and understanding of the environment. Perception includes all signals in the nervous system, which are the result of physical or chemical stimulation of the sensing organs.

The results of the study showed that out of 88 respondents (100\%) in the good perception category were 50 respondents $(56.8 \%)$, who were in arrears in payment of 22 respondents ( $25.0 \%$ ) this was due to the knowledge of respondents who still did not understand the function health insurance, which is not in arrears as much as 28 respondents ( $31.8 \%$ ) this was due to the respondents aware of the importance of paying dues to get health insurance that deserves to be supported by the perception of respondents about health insurance, as well as sufficient income. While respondents who have less perception are 38 
respondents $(43.2 \%)$, who are delinquent as many as 32 respondents ( $36.4 \%$ ) because the respondents' perceptions who think can still get health insurance from the organizing body when sick and directly pay arrears, which are not arrears as much as six respondents ( $6.8 \%$ ). This is because respondents get support and motivation from family members who understand the rules of getting health insurance and adequate income .

Based on the statistical test result, $p(0.000)$ is smaller than $\alpha(p<\alpha 0.05)$, the hypothesis means that $\mathrm{H}_{0}$ is rejected or $\mathrm{H}_{1}$ received, which means there is a relationship between non-payment of dues BPJS to unite in PHC Abeli Kendari City in 2018. The results of this study are in line with research conducted by Rismawati (2017) which shows that perceptions have a meaningful relationship with compliance paying independent BPJS contributions in the work area of the Batalaiworu Community Health Center. But not in line with research conducted by Pratiwi (2015) which is seen from the results of the Chi Square test showed there was no significant relationship between perceptions with compliance paying BPJS contributions independently.

\section{Conclusions}

Based on the results of research and discussion on research on factors related to arrears of payment of independent health BPJS contributions in the work area of the Kendari City Abeli Health Center, it can be concluded There is a strong enough relationship between knowledge and the arrears of BPJS contribution payments in the work area of the Abeli Health Center in Kendari City, There is a strong relationship between the overdue and delinquency payment of BPJS contributions in the work area of the Kendari City Abeli Health Center, There is a fairly strong relationship between perception and the arrears payment of the BPJS contribution in the work area of the Abeli Health Center in the City of Kendari . 
Based on the conclusions of the results of the research conducted, there are a number of suggestions in this research namely, For the health BPJS to provide information or information to BPJS participants so that participants understand about the BPJS program and the rules and obligations of BPJS participants, For Puskesmas to improve the quality of services and serve without distinguishing BPJS and Non-BPJS patients, For further research, the Researcher hopes for further research related to the problem of arrears in payment of BPJS contributions using other variables .

\section{Acknowledgment}

The author conveys with utmost respect, expressing his unlimited thanks. A big thank you to the author also to the Mandala Waluya Foundation for giving us the opportunity to carry out the tridharma of tertiary education especially in education. Related parties are the participants of the BPJS Mandiri community in the Abeli Puskesmas working area, Kendari City. Thank you for the availability of time and location during the study, and all parties for their motivation and support.

\section{References}

1. Health BPJS. 2014. Service Guide for BPJS Health Participants . Jakarta: Agency for Managing Social Health Hours .

2. Republic of Indonesia Ministry of Health 2014. Regarding BPJS Health . Jakarta : The Indonesian Ministry of Health.

3. BPJS. 2016. P anduan Practical Tiered Referral System . Jakarta : Health Social Security Organizing Agency . 
4. Rismawati et

al . 2017.

Factors Related

Decision

Against

Paying I Uran BPJS Mandiri in Puskesmas Batalaiworu Batalaiworu District of Muna . Scientific Journal of Public Health Students. Faculty of Public Health. Halu Oleo University.

5. PHO ProviQuSultra. 2017. BPJS Membership Data Southeast Sulawesi Province . DHO. Kendari : Southeast Sulawesi Provincial Health Office.

6. PuskesmasAbeli. 2018 Profile of the Abeli Community Health Center. Kendari :Abeli Community Health Center.

7. Notoatmodjo S. 2007 . Principles - Basic Principles of Public Health Sciences . Jakarta: PT. RinekaCipta.

8. Pratiwi AN. 2016. Factors Influencing Regularity to Pay Contribution to Participants in the National Health Insurance (JKN) Independent Participant Category (Case study of inpatients at Dr. Soebandi Hospital ,Jember Regency) . Administration and Health Policy Section, Faculty of Public Health, University of Jember...http : //repository.unej.ac.id. Accessed November 12, 2018

9. Nopiyani NMS 2015. Determinant Analysis of Compliance and Development of a Strategy to Increase Compliance Payment of Contributions to Non-PBI Independent JKN Participants with the Health BPJS Research and Development Group in Denpasar City . Faculty of Medicine, UdayanaUniversity .

10. Kertayasa. 2010 . Factors Associated with the Willingness to Pay Health Funds Contribution Regularly in the Village of Death in Sukaraja District, Bogo Regency r . http://lib.ui.ac.id/opac/themes/libri.id . Accessed November 12, 2018. 